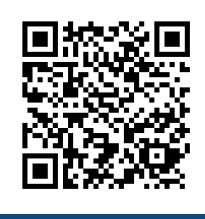

Keywords: Forest villages Financial ranking Cooperatives TOPSIS

Rural development

Historic: Received 06/03/2018 Accepted 23/08/2018

Correspondence: korkmazmehmet32@gmail.com
Mehmet Korkmaz ${ }^{1+}$, Demet Gurer ${ }^{2}$

\section{FINANCIAL PERFORMANCE EVALUATION OF FOREST VILLAGE COOPERATIVES: A MULTI-CRITERIA TOPSIS APPROACH}

KORKMAZ, M.; GURER, D. Financial performance evaluation of forest village cooperatives: a multi-criteria topsis approach. CERNE, v. 24, n. 3, p. 280-287, 2018.

\section{HIGHLIGHTS}

Financial performance is one of the most important indicators of success.

TOPSIS is an appropriate method to put the cooperatives in order of financial performance.

Financial performances of all the cooperatives were low in the years.

Working area of the cooperatives should be extended

\section{ABSTRACT}

Forest villagers constitute the poorest of the society in underdeveloped and developing countries. Efforts for the rural development of forest villages are important for combating poverty, regulating the relationship with forest villagers, and ensuring sustainable management of forests, since rural people subsist on forest lands. As the most important method of executing an organized movement in such settlement areas, cooperatives represent one of the most crucial actors in rural development. However, it seems that cooperatives cannot provide adequate contribution to the rural development in Turkey. This research analyses the financial performance of the cooperatives operating in the forest villages located within the boundaries of Bucak and Sutculer forest districts, where forestry activities are carried out intensively in Turkey. This study uses the TOPSIS method, which is a multi-criteria decision-making method. The results of the study revealed that the financial performances of all of the cooperatives were low during the years when they were analysed. The most important reasons for low financial performance include the fact that: (i) the cooperatives mainly operated in the field of wood production and the business volume in that field was inadequate, (ii) their capital was insufficient since the members assumed a lower share, (iii) they had challenges accessing constant funds for investment, (iv) the state subsidies decreased, (v) the number of members was low, and (vi) they were unable to compete with large companies. 


\section{INTRODUCTION}

Poor rural people living in forest villages depend on forest resources in underdeveloped and developing countries. It is important to alleviate poverty within these villages with a focus on regulating the relationships between the rural people and protecting forests (Dewi et al., 2005).

The mobilization of rural dynamics and realization of organized instead of individual efforts in forest villages can be achieved through cooperatives. Cooperatives are the most active organizations for rural development and food safety (Chagwisa et al., 2016). In other words, cooperatives play a key role in achieving rural development. The forest village cooperatives are mainly engaged in wood production that includes cutting, logging operations, and transportation processes. Therefore, forestry activities constitute the main field of activity for these cooperatives (Atmis et al., 2007). Cooperatives in forest villages differ from other agricultural cooperatives in terms of certain aspects such as business models, market characteristics, and investment density (Berlin and Erikson, 2007).

Cooperatives have long been considered an important tool in the development of rural settlements in Turkey. The cooperative system was introduced in Turkey with a fraternal organization established in 1863 (Ozdemir, 198I). Efforts to create a modern cooperative system, however, date back to the period after the proclamation of the Republic of Turkey in 1923. The first cooperative in forest villages was established in 1963 with the goal of sending workers to Western Germany. Like in many underdeveloped and developing countries, contemporary and coherent policies on cooperatives could not be developed in Turkey, and they did not realize their potential to ensure economic and social development. Similarly, with the exception of some successful cooperatives, forest village cooperatives could not generate the benefits they attempted to provide regarding certain matters such as achieving the socioeconomic and cultural development of rural areas, preventing migration from rural areas to urban areas, and reducing the pressure on forests, and could not fulfil the purpose of establishment due to macro and micro factors (Alkan and Toksoy, 2008).

Several factors had an effect on the failure of the cooperatives in rural areas, the most significant of which is inadequate financial means (Fahlbeck, 2007). Inadequate capital, members assuming lower shares, lack of loans, and high interest rates are some of the specific financial challenges that can arise (Toksoy et al., 2009; Alkan and Demir, 2013). Furthermore, socio-economic and cultural factors may also contribute to the failure of cooperatives (Avsec and Stromajer, 2015).
The financial performance of the cooperatives in rural areas has been evaluated in several studies conducted by Carlberg et al. (2006), Boyd et al. (2007), Gurung and Unterschultz (2007), McKee (2007), McKee (2008), Cosgun et al. (2008), Sharifi (20I3), and Quilloy (2015). These studies evaluated separately the ratios determined for the analysis of financial performance.

In this study, the financial performance of the cooperatives operating in the forest villages located within the boundaries of Bucak and Sutculer forest districts, where forestry activities are carried out intensively in Turkey, was analysed using the Technique for Order Preference by Similarity to Ideal Solution (TOPSIS) method, which is a multi-criteria decision-making method, thereby all ratios could be evaluated together.

\section{MATERIAL AND METHODS}

\section{Study Area}

For the study area, cooperatives $(n=35)$ operating in forest villages located within the boundaries of the Bucak and Sutculer forest districts in West Mediterranean Region of Turkey were selected (Figure I). The main reasons for the selection of that area were as follows. The ratio of the forestlands to total area (Table I) is high in Bucak (77.55\%) and Sutculer (68.69\%) forest districts and there are an intensive production of industrial wood. In Bucak and Sutculer, the most important income of the cooperatives is obtained from the process of industrial wood production and cooperatives have existed in the area for many years and thus they had a significant experience with respect to cooperative activities.

All of the cooperatives operating in the field of forestry activities included primarily wood production, afforestation, and forest construction. The main means of existence for the cooperatives operating in the region was derived from wood production processes. Cutting, logging operations, and transportation processes, which are the main wood production stages, were carried out by the cooperatives. This is an indication that the forest villagers heavily depend on forest resources.

\section{Data collection}

In order to determine the financial performance under this study, five-year data covering 2009-20I 3 were obtained from the balance sheets and income statements of the cooperatives, which were their main financial statements. Furthermore, semi-structured interviews were held with the managers of the cooperatives, through which financial problems and proposed solutions were identified. All of the cooperative managers interviewed 
TABLE I Distribution of areas in Bucak and Sutculer forest districts.

\begin{tabular}{ccccccc}
\hline Forest & $\begin{array}{c}\text { Normal } \\
\text { forest } \\
\text { district }\end{array}$ & $\begin{array}{c}\text { Degraded } \\
\text { forest } \\
\text { (ha) }\end{array}$ & $\begin{array}{c}\text { Total } \\
\text { forest } \\
\text { (ha) }\end{array}$ & $\begin{array}{c}\text { Non } \\
\text { forest } \\
\text { (ha) }\end{array}$ & $\begin{array}{c}\text { Total area } \\
\text { (ha) }\end{array}$ & $\begin{array}{c}\text { Forest } \\
\text { area } \\
\%\end{array}$ \\
\hline
\end{tabular}

Bucak 39172.0031124 .2070296 .2020350 .8090647 .0077 .55

Sutculer $54794.00 \quad 42483.20 \quad 97277.20 \quad 44343.70$ I4I620.90 68.69

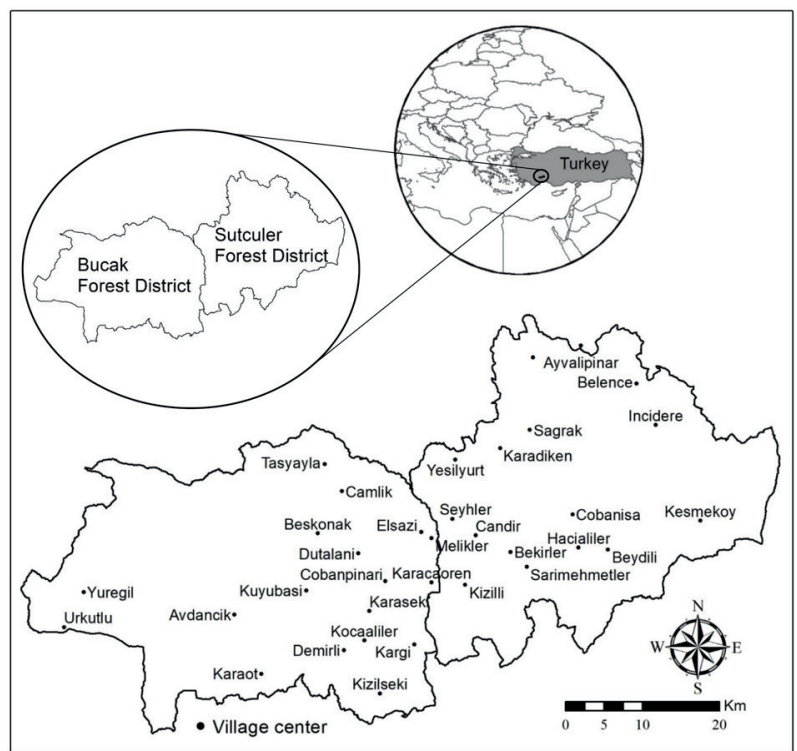

FIGURE I Location of forest village cooperatives in Bucak and Sutculer forest districts in West Mediterranean Region of Turkey.

are male. Some of the managers' socio-demographic characteristics are shown in Table 2.

Cooperatives differ from business enterprises with respect for their objectives and practices. Therefore, the studies conducted by Cosgun et al. (2008) and Quilloy (2015) served as the basis to determine the ratios used to analyse the cooperatives' financial performance. One of the ratios was an indicator of leverage, the other

TABLE 2 Classification of the cooperative managers according to their characteristics.

\begin{tabular}{ccc}
\hline Characteristics & Number & $\%$ \\
\hline Age & & \\
$20-40$ & 10 & 28.6 \\
$4 \mathrm{I}-60$ & 23 & 65.7 \\
$>60$ & 2 & 5.7 \\
\hline Managing year & & \\
\hline I-3 & 15 & 42.8 \\
$4-6$ & 10 & 28.6 \\
$>6$ & 10 & 28.6 \\
\hline Education level & & \\
\hline Elementary school & 23 & 65.8 \\
Secondary school & 7 & 20.0 \\
High school & 5 & 14.2 \\
University & - & - \\
\hline
\end{tabular}

two indicated financial structure, another indicated profitability, and the last one was an indicator of liquidity. The definitions of these ratios are provided in Table 3, while Table 4 presents the descriptive statistics. Debt ratio (DR): Showing the part of the total assets that is funded by foreign resources, this ratio also provides information about the distribution of the total resources of the cooperatives. Equity ratio (ER): This ratio shows which of the cooperative's assets are derived from equity. Short-term debt to total liabilities ratio (STDL): This ratio shows which of the cooperative's assets are financed by short-term foreign resources. Return on assets ratio (ROA): This ratio is used to measure the size of the cooperatives and their efficiency and shows to what extent all assets of the cooperative (including the tangible and financial investments) are used effectively. Net working capital to net total asset ratio (NWCA): Showing the proportion of working capital needed among the total assets by the cooperatives to survive, this ratio determines whether the net working capital is at optimal level to meet the needs of the cooperatives.

TABLE 3 Financial ratios used for the performance analysis of forest village cooperatives.

\begin{tabular}{ccc}
\hline Ratio & Performance indicator & Definition \\
\hline DR & Leverage & Total Dept/Total Assets \\
ER & Financial statement & Total Equity/Total Assets \\
STDL & Financial statement & Short-term Dept/Total Liabilities \\
ROA & Profitability & Net Income/Total Assets \\
NWCA & Liquidity & Net Working Capital/Net Total Assets \\
\hline
\end{tabular}

TABLE 4 Descriptive statistics related to financial ratios used in performance analysis.

\begin{tabular}{cccccc}
\hline Ratio & $\mathrm{N}$ & Minimum & Maximum & Mean & Std. deviation \\
\hline DR & 175 & 0.00 & 4.23 & 0.59 & 0.52 \\
ER & 175 & -3.23 & 1.00 & 0.41 & 0.52 \\
STDL & 175 & 0.00 & 18.86 & 2.73 & 1.45 \\
ROA & 175 & -8.71 & 0.75 & -0.08 & 0.91 \\
NWCA & 175 & -3.79 & 1.00 & 0.07 & 0.59 \\
\hline
\end{tabular}

Data Analysis

The data collected regarding financial performance were analysed based on the ratios using TOPSIS, which is one of the multicriteria decision-making methods. TOPSIS uses the main approaches in ELECTRE (ELimination Et Choix Traduisant la REalité). But this method's solution process based on the principle of similarity is shorter compared to that of ELECTRE (Yilmaz et al., 2010; Kucas, 20I I; Korkmaz, 2012; Prato and Paveglio, 2014). TOPSIS consists of six steps as follows (Feng and Wang, 2000; Behzadian et al., 20I2): 
Step I: Decision matrix is normalized via Equation $\mathrm{I}$, where, $i$ is the $i$ th cooperative, $j$ the $j$ th performance ratio, $r_{i j}$ the ratio value after vector normalization for the ith cooperative and $j$ th performance ratio, $a_{i j}$ the original value of ratios for the ith cooperative and $j$ th performance ratio and $m$ the number of cooperatives.

$$
\begin{aligned}
& \mathrm{j}=1,2,3, \ldots, \mathrm{j}, \mathrm{i}=\mathrm{I}, 2,3, \ldots, \mathrm{m} \\
r_{(i j)}= & \frac{a_{(i j)}}{\sqrt{\left(\sum_{(i=1)}^{m} a_{(j)}^{2}\right)}}
\end{aligned}
$$

Step 2: Weight normalized decision matrix is

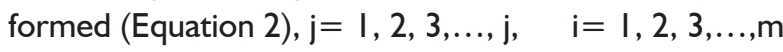

$$
v_{(i j)}=w_{i} \cdot r_{(i j)}
$$

Step 3: To determine ideal $\left(A^{+}\right)$and worst $\left(A^{-}\right)$ solution (Equation 3 ). Where $J=\{j=1,2, \ldots k \mid k$ belongs to benefit criteria $\}, J^{\prime}=\{j=1,2, \ldots k \mid k$ belongs to cost criteria\}. $i=I, 2,3, \ldots, m$.

$$
\begin{aligned}
A^{+}= & \left\{\left(\max _{i} v_{i j} \mid j \in J\right),\left(\min _{i} v_{i j} \mid j \in J^{\prime}\right)\right\} \\
= & \left\{A_{1}^{+}, A_{2}^{+}, \ldots, A_{j}^{+}, \ldots, A_{k}^{+}\right\} \\
A^{-}= & \left\{\left(\min _{i} v_{i j} j \in J\right),\left(\max _{i} v_{i j} j \in J^{\prime}\right)\right\} \\
= & \left\{A_{1}^{-}, A_{2}^{-}, \ldots, A_{j}^{-}, \ldots, A_{k}^{-}\right\}
\end{aligned}
$$

Step 4: To calculate the separation measure: The separation of each cooperative from the ideal one $\left(\mathrm{S}_{i}^{+}\right)$ and the worst one $\left(S_{i}^{-}\right)$is then respectively given by equation 5 and 6 , where $i=1,2, \ldots, \mathrm{m}$.

$$
\begin{aligned}
& S_{i}^{+}=\sqrt{\left(\sum_{(j=1)}^{k}\left(v_{(i j)}-A_{j}^{+}\right)^{2}\right)} \\
& S_{i}^{-}=\sqrt{\left(\sum_{(j=1)}^{k}\left(v_{(i j)}-A_{j}^{-}\right)^{2}\right)}
\end{aligned}
$$

Step 5: To calculate the relative closeness to the ideal solution $\left(C_{i}^{*}\right)$ : It is defined in equantion I, where $0 \leq \mathrm{C}_{\mathrm{i}}^{*} \leq \mathrm{I}$.

$$
C^{*}=\frac{\left(S_{i}^{-}\right)}{\left(S_{i}^{+}+S_{i}^{-}\right)}
$$

Step 6: Rank the preference order: According to the descending order of $C_{i}^{*}$.

The differences found between the rankings according to TOPSIS results were determined through ANOVA and Tukey HSD test.

\section{RESULTS AND DISCUSSION}

\section{Financial performance ranking of cooperatives}

The cooperatives' financial performance was listed in order first by years and then according to the five-year averages of the ratios. The order of the cooperatives' financial performance by years according to TOPSIS results is indicated in Table 5. The order of the cooperatives varies by year. For example, the Beskonak Cooperative that was in the first place in 2009 ranked in nineteenth place in 2010 and thirty-second in 2012. This was in contrast to the Avdancik Cooperative, which was in twenty-fifth place in 2009 while it ranked in the top five in 20I I, 20l2, and 20l3. The Sagrak and Bekiragalar cooperatives usually ranked in higher spots, which was noteworthy. In the order according to five-year averages (Table 6), Sipahiler (0.699), Bekiragalar (0.548), Avdancik (0.54I), Sagrak (0.537), and Karaot (0.52I) were among the top five cooperatives.

Regarding the similarity of the cooperatives in the process of reaching an ideal solution $(C i *=I)($ Table 7), $C$ i* values were found to be low across the entire region and in each forest district. In other words, the cooperatives demonstrated low financial performance. Our results correspond with the findings of Cosgun et al. (2008) and Quilloy (2015). The highest Ci* values were recorded in 2009 , while they decreased in the subsequent years. The financial performance of the cooperatives continued to decrease until 201 I, after which it started to increase again. This result was statistically significant $(p<0.05)$. The ANOVA results show that the years 2009 and $201 \mathrm{I}$ represented separate sub-groups, whereas two separate sub-groups were found in the other years (Table 8 ).

Problems and expectations according to cooperative managers

The main reasons for low financial performance included primarily concentration on wood production and inability to operate in the other production areas to meet the market demand. The cooperatives in the forest villages have so far been substantially engaged in wood production. Today, some of the forest areas in Turkey that were intended for used in wood production in the past according to multi-objective forest planning (Pukkala, 2002) are allocated to other functions (water production, wildlife function, etc.). Therefore, business volume has decreased in some of the planned units due to the reduction in the production amount of wood production, which leads to the decreased income of 
TABLE 5 Financial performance ranking of forest village cooperatives by years.

\begin{tabular}{|c|c|c|c|c|c|c|c|c|c|c|c|}
\hline \multirow{2}{*}{$\begin{array}{l}\text { Forest } \\
\text { District }\end{array}$} & \multirow{2}{*}{ Cooperative } & \multicolumn{2}{|c|}{2009} & \multicolumn{2}{|c|}{2010} & \multicolumn{2}{|c|}{2011} & \multicolumn{2}{|c|}{2012} & \multicolumn{2}{|c|}{2013} \\
\hline & & $\mathrm{Ci}$ & Rank & $\mathrm{Ci}$ & Rank & Ci* & Rank & $\mathrm{Ci}$ & Rank & $\mathrm{Ci}$ & Rank \\
\hline \multirow{18}{*}{ Sutculer } & Kizilli & 0.583 & 29 & 0.480 & 22 & 0.297 & 26 & 0.410 & 25 & $0.46 \mathrm{I}$ & 24 \\
\hline & Candir & 0.571 & 32 & 0.474 & 27 & 0.180 & 35 & 0.546 & 3 & 0.443 & 26 \\
\hline & Melikler & 0.594 & 16 & 0.494 & 14 & 0.355 & 15 & 0.444 & 13 & 0.484 & 16 \\
\hline & Seyhler & 0.593 & 17 & 0.569 & 2 & 0.273 & 31 & 0.392 & 27 & 0.517 & 6 \\
\hline & Yesilyurt & 0.615 & 4 & 0.499 & II & 0.314 & 22 & 0.490 & 6 & 0.516 & 7 \\
\hline & Karadiken & 0.577 & 31 & 0.635 & I & 0.272 & 32 & $0.35 I$ & 33 & $0.56 \mathrm{I}$ & 2 \\
\hline & Sagrak & 0.566 & 33 & 0.525 & 3 & 0.487 & 2 & 0.425 & 21 & 0.577 & I \\
\hline & Bekiragalar & 0.617 & 3 & 0.525 & 4 & 0.410 & 9 & 0.531 & 4 & 0.546 & 3 \\
\hline & Sarimehmetler & 0.622 & 2 & 0.491 & 16 & 0.330 & 17 & 0.442 & 15 & 0.507 & 8 \\
\hline & Hacialiler & 0.589 & 24 & 0.494 & 15 & 0.419 & 7 & 0.394 & 26 & 0.394 & 34 \\
\hline & Cobanisa & 0.607 & 5 & 0.465 & 29 & 0.232 & 34 & 0.380 & 31 & 0.411 & 33 \\
\hline & Beydili & 0.387 & 34 & 0.462 & 30 & 0.263 & 33 & 0.335 & 35 & 0.430 & 27 \\
\hline & Sipahiler & 0.586 & 27 & 0.477 & 25 & 0.519 & I & 0.433 & 16 & 0.449 & 25 \\
\hline & Yuvali & 0.584 & 28 & 0.485 & 18 & 0.275 & 30 & 0.420 & 22 & 0.423 & 31 \\
\hline & Ayvalipinar & 0.600 & 11 & 0.502 & 10 & 0.405 & 11 & 0.428 & 19 & 0.484 & 17 \\
\hline & Belence & 0.590 & 22 & 0.490 & 17 & 0.342 & 16 & 0.431 & 17 & 0.474 & 22 \\
\hline & Kesmekoy & 0.593 & 18 & 0.514 & 8 & 0.326 & 18 & 0.443 & 14 & 0.491 & 14 \\
\hline & İncedere & 0.581 & 30 & 0.495 & 12 & 0.407 & 10 & $0.48 \mathrm{I}$ & 8 & 0.493 & 12 \\
\hline \multirow{17}{*}{ Bucak } & Karaot & 0.595 & 13 & 0.516 & 7 & 0.417 & 8 & 0.460 & II & 0.421 & 32 \\
\hline & Kuyubasi & 0.602 & 8 & 0.508 & 9 & 0.321 & 20 & $0.47 \mid$ & 10 & 0.498 & 9 \\
\hline & Avdancik & 0.588 & 25 & 0.520 & 6 & 0.460 & 3 & 0.495 & 5 & 0.536 & 5 \\
\hline & Yuregil & 0.594 & 15 & 0.386 & 34 & 0.323 & 19 & 0.380 & 30 & 0.495 & 10 \\
\hline & Urkutlu & 0.596 & 12 & 0.523 & 5 & 0.296 & 27 & 0.389 & 28 & 0.476 & 18 \\
\hline & Tasyayla & 0.592 & 19 & 0.480 & 20 & 0.311 & 23 & 0.430 & 18 & 0.462 & 23 \\
\hline & Camlik & 0.592 & 20 & 0.480 & 21 & 0.306 & 24 & 0.385 & 29 & 0.475 & 21 \\
\hline & Elsazi & 0.588 & 26 & 0.466 & 28 & 0.398 & 12 & 0.484 & 7 & 0.494 & 11 \\
\hline & Dutalan & 0.595 & 14 & 0.440 & 33 & 0.283 & 28 & 0.556 & I & 0.491 & 13 \\
\hline & Kargi & 0.356 & 35 & $0.46 \mathrm{I}$ & 31 & 0.357 & 14 & 0.553 & 2 & 0.326 & 35 \\
\hline & Demirli & 0.592 & 21 & 0.479 & 23 & 0.314 & 21 & 0.410 & 24 & 0.476 & 19 \\
\hline & Kizilseki & 0.601 & 10 & 0.494 & 13 & 0.375 & 13 & 0.416 & 23 & $0.54 I$ & 4 \\
\hline & Kocaaliler & 0.589 & 23 & 0.455 & 32 & 0.276 & 29 & 0.427 & 20 & 0.428 & 28 \\
\hline & Beskonak & 0.630 & I & $0.48 \mathrm{I}$ & 19 & 0.303 & 25 & 0.370 & 32 & 0.427 & 29 \\
\hline & Karacaoren & 0.602 & 9 & 0.477 & 24 & 0.428 & 5 & 0.457 & 12 & 0.476 & 20 \\
\hline & Cobanpinar & 0.606 & 6 & 0.366 & 35 & 0.423 & 6 & 0.474 & 9 & 0.425 & 30 \\
\hline & Karaseki & 0.603 & 7 & 0.476 & 26 & 0.457 & 4 & 0.347 & 34 & 0.484 & 15 \\
\hline
\end{tabular}

TABLE 6 Financial performance ranking according to the five-year average of financial ratios of forest village cooperatives.

\begin{tabular}{cccccccccccc}
\hline Cooperative & Ci* & Rank & Cooperative & Ci* & Rank & Cooperative & Ci* & Rank & Cooperative & Ci* & Rank \\
\hline Sipahiler & 0.699 & $\mathrm{I}$ & Yesilyurt & 0.506 & 10 & Tasyayla & 0.486 & 19 & Candir & 0.455 & 28 \\
Bekiragalar & 0.548 & 2 & Melikler & 0.504 & 11 & Karaseki & 0.485 & 20 & Yuvali & 0.455 & 29 \\
Avdancik & $0.54 \mathrm{I}$ & 3 & Hacialiler & 0.504 & 12 & Seyhler & 0.483 & 21 & Kocaaliler & $0.44 \mathrm{I}$ & 30 \\
Sagrak & 0.537 & 4 & Kizilseki & 0.503 & 13 & Camlik & 0.480 & 22 & Cobanisa & 0.427 & 31 \\
\hline Karaot & 0.521 & 5 & Urkutlu & 0.495 & 14 & Beskonak & 0.480 & 23 & Kargi & 0.423 & 32 \\
\hline Ayvalipinar & 0.518 & 6 & Sarimehmetler & 0.495 & 15 & Demirli & 0.479 & 24 & Beydili & $0.37 \mathrm{I}$ & 33 \\
Kesmekoy & 0.514 & 7 & Belence & 0.492 & 16 & Kizilli & 0.474 & 25 & Yuregil & 0.370 & 34 \\
Kuyubasi & 0.513 & 8 & Karacaoren & 0.491 & 17 & Elsazi & 0.468 & 26 & Cobanpinar & 0.368 & 35 \\
\hline Incedere & 0.508 & 9 & Karadiken & 0.488 & 18 & Dutalan & 0.459 & 27 & Mean & 0.485 & \\
\hline
\end{tabular}

TABLE 7 The average of relative closeness to the ideal solution ( $\mathrm{Ci}$ * values by years.

\begin{tabular}{cccccc}
\hline & 2009 & 2010 & 2011 & 2012 & 2013 \\
\hline All Cooperatives & 0.582 & 0.488 & 0.347 & 0.437 & 0.474 \\
Cooperatives in Bucak Forest District & 0.584 & 0.471 & 0.356 & 0.441 & 0.467 \\
Cooperatives in Sutculer Forest District & 0.581 & 0.504 & 0.339 & 0.432 & 0.48 I \\
\hline
\end{tabular}


TABLE 8 Differences between years according to TOPSIS results.

\begin{tabular}{cc}
\hline Year & Mean \\
\hline 2011 & $0.347^{\mathrm{a}}$ \\
2012 & $0.437^{\mathrm{b}}$ \\
2013 & $0.474^{\mathrm{bc}}$ \\
2010 & $0.488^{\mathrm{c}}$ \\
2009 & $0.582^{\mathrm{d}}$ \\
\hline
\end{tabular}

the cooperatives. Additional reasons according to cooperative managers are as follows: a) Inadequate capital since the cooperative members assume lower membership shares; b) Absence of infrastructure for the access of cooperatives to the financial resources they need for investments; c) Lack of access to funding and inadequate guarantees; d)Decreasing government subsidies for cooperatives; e)Low number of members in the cooperatives, small scale operation, and inability to compete with large firms.

There was a lack of collaboration between the cooperatives that were analysed. This is explained by the fact that each village had a small-scale cooperative. In particular, it is important to create larger cooperatives by encouraging the merging of the existing cooperatives and enabling them to gain a more professional structure (Österberg and Nilsson, 2009).

Financial problems are especially associated with the structural characteristics of the cooperatives (Chaddad et al., 2005). The following structural problems were identified: a)Poor educational background and thus lack of awareness about cooperatives and inability to disseminate them; b)Lack of knowledge and experience among cooperative managers in business administration, inability to hire professional managers; c)Low level of social capital including interpersonal trust, solidarity, and joint operation culture; d)Lack of understanding about the contributions and benefits of economic cooperation.

The management of the cooperatives faced several problems; $51.5 \%$ had issues with their members. These problems were expressed as the lack of interest among the members and inability to act collectively for the objectives of the cooperative. Tilahun et al. (2016) stated that the members of a cooperative had a lower poverty rate compared to the non-members and emphasized the importance of collaborative work. The solution to this problem may also contribute positively to the cooperatives' forestry activities (Atmis et al., 2009).

As the forest villagers depend on forest resources both economically and socially, some of the decisions of forest districts may lead to negative perceptions about forests and forestry (Alkan et al., 2009; Alkan, 2009). Only $20 \%$ of the cooperatives in the region had issues with the forest districts, which indicates that the relationships between the forest districts and cooperatives were considerably positive.

The most important suggestion by cooperative managers for the success of cooperatives and their role in rural development is to strengthen the financial structures of cooperatives. In order to implement this suggestion, a funding agency can be established to raise the value of the partnership, to establish a creditguarantee fund so that the cooperatives can borrow the bank credits to be used, and to meet the financing needs of the cooperatives in order to strengthen the ownership structure of the cooperatives. Another suggestion for cooperative success is the expansion of the activity areas. As mentioned earlier, cooperatives in the forest villages of Turkey concentrate on the industrial and fire wood production from the past. Therefore, it is important for cooperatives to expand their field of activities in the production of non-wood forest products, agriculture, or animal husbandry. Another important proposal involves training workers on partnership culture, entrepreneurship, and cooperative awareness.

According to the cooperative managers, credit support is at the forefront of the suggestions for the state to help the cooperatives succeed. However, the government loans provided to forest villages in Turkey did not sufficiently contribute to the financial development of the cooperatives (Alkan and Kilic, 20l4). Moreover, the government subsidies for cooperatives have been declining. Another method of state assistance is state support for training activities. Cooperatives could more effectively plan training activities in coordination with ministries, trade unions, and non-governmental organizations. These trainings should be implemented through a project called Cooperative Entrepreneurship Training (DGC, 2012). Significant differences were found statistically between the level of education and the answers given by the cooperative managers. Primary and secondary school graduates support credit, and a large part of high school graduates indicate that the government should provide education (Chi-square $=26.603 ; \mathrm{p}<0.05)$.

\section{CONCLUSIONS}

Financial performance is one of the most important indicators of success. TOPSIS is an appropriate method by which to examine the cooperatives' financial performance. For instance, through this analysis, it is possible to answer the question regarding which cooperatives will have priority in accessing the supports provided by the state and private financial institutions, because the ranking of the cooperatives starts with those with the best financial performance according to TOPSIS 
results. The financial performance of the cooperatives should be improved for their success and to increase their role in rural development. To this end, it can be suggested that the working areas of the cooperatives be extended (e.g. production and marketing of nonwood forest products), their membership shares be increased, a loan-guarantee fund be created to enable the cooperatives to provide guarantees for bank loans, and a financial institution be established to meet the funding needs of the cooperatives.

\section{REFERENCES}

ALKAN, H. Negative impacts of rural settlements on natural resources in the protected areas: An example from Kovada Lake National Park. Journal of Environmental Biology, v.30, n. 3, p. 363-372, 2009.

ALKAN, H.; Demir, E. Factors affecting the development of cooperatives in forest villages. SDU Faculty of Forestry Journal, v. I4, n. I, p. I-9, 2013.

ALKAN, H.; KILIC, M. Forests and forestry organizations from the forest villagers' perspective: a case study from Turkey. iForest, v. 7, p. 240-247, 2014.

ALKAN, H.; KORKMAZ, M.; TOLUNAY, A. Assessment of primary factors causing positive or negative local perceptions on protected areas. Journal of Environmental Engineering and Landscape Management, v. I7, n. I, p. 20-27, 2009.

ALKAN, S.; TOKSOY, D. The socio-economic structure of the forest villages: The case study in Trabzon. Kastamonu Univ., Journal of Forestry Faculty, v. 8, n. I, p. 37-46, 2008.

ATMIS, E.; GUNSEN, H.B.; LISE, B.B.; LISE, W. Factors affecting forest cooperative's participation in forestry in Turkey. Forest Policy and Economics, v. I I, p. I02-I08, 2009.

ATMIS, E.; ÖZDEN, S.; LISE, W. Public participation in forestry. Ecological Economics, v. 62, p. 352-359, 2007.

AVSEC, F; STROMAJER, J. Development and socioeconomic environment of cooperatives in Slovenia. Journal of Cooperative Organization and Management, v.3, p. 40$48,2015$.

BEHZADIAN, M.; OTAGHSARA, S. K.; YAZDANI, M.; IGNATIUS, J.' A state-of the-art survey of TOPSIS applications. Expert Systems with Applications, v.39, p. |305|-|3069, 2012.

BERLIN, C.;ERIKSON, L.O. A comparison of characteristics of forest and farm cooperative members. Journal of Cooperatives, v. 20, p. 50-63, 2007.

BOYD, S.; BOLAND, M.; DHUYVETTER, K.; BARTON, D. Determinants of return on equity in US. local farm supply and grain marketing cooperatives. Journal of Agricultural and Applied Economics, v. 39, n. I, p. 20I-2 I0, 2007.
CARLBERG, J.G.; WORD, C.E.; HOLCOMB, R.B. Success factors of new generation cooperatives. International Food and Agribusiness Management Review, v. 9, n. I, p. 33-52, 2006.

CHADDAD, F.R.; COOK, M.L.; HECKELEI, T. Testing for the presence of financial constraints in US agricultural cooperatives: An investment behaviour approach. Journal of Agricultural Economics, v. 56, n. 3, p. 385-397, 2005.

CHAGWISA, C.; MURADIAN, R.; RUBEN, R. Cooperative membership and dairy performance among smallholders in Ethiopia. Food Policy, v. 59 p. 165-I73, 2016.

COSGUN, U.; BEKIROGLU, S.; TELEK, A. Determination of efficiency at the level of agriculture development cooperatives in forest villages: The study case in Antalya. Southwest Anatolia Forest Research Institute, Technical bulletin No:34, Turkey, 2008.

DGC, Turkish Cooperatives Strategy and Action Plan (20I2-2016). Directorate General of Cooperatives, Ministry of Customs and Trade, Ankara/Turkey, 20I2, 68p.

DEWI, S.; BELCHER, B.; PUNTODEWO, A. Village economic opportunity, forest dependence, and rural livelihoods in East Kalimantan, Indonesia. World Development, v. 33, n. 9, p. I4|9-|434, 2005.

FAHLBECK, E. The Horizon Problem in Agricultural Cooperatives - only in Theory? In: Vertical Markets and Cooperative Hierarchies: The Role of Cooperatives in the Agri-Food Industry, Karantininis K, Nilsson J(Eds). Springer, Netherlands. p. 255-274, 2007.

FENG, C.M.; WANG, R.S. Performance evaluation for airlines including the consideration of financial ratios. Journal of Air Transport Management, v. 6, n. 3, p. I33-|42, 2000.

GURUNG, R.K., UNTERSCHULTZ, J.R. Evaluation of factors affecting the choice of pricing and payment practices by traditional marketing and new generation cooperatives. Journal of Cooperatives, v. 20, p. I8-32, 2007.

KUCAS, A. Location Prioritization by means of multicriteria spatial decision-support systems: A case study of forest fragmentation-based ranking of forest administrative areas. Journal of Environmental Engineering and Landscape Management, v. 18, n.4, p. 312-320, 2011.

KORKMAZ, M. Analysis of economic efficiency at forest enterprises with TOPSIS method. SDU Faculty of Forestry Journal, v. I3, p. I4-20, 2012.

MCKEE, G. The Financial Performance of North Dakota Agricultural Cooperatives. Department of Agricultural Economics North Dakota State University, Agribusiness and Applied Economics Report No: 624, p. 19, 2007.

MCKEE, G. The financial performance of North Dakota grain marketing and farm supply cooperatives. Journal of Cooperatives, v. 21, p. 15-34, 2008. 
OZDEMIR N. Cooperatives. Academy of Economic and Commercial Sciences Pub. No: 163, Ankara/Turkey, p. 169, 1981.

ÖSTERBERG, P.,NILSSON, J. Members' perception of their participation in the governance of cooperatives: The key to trust and commitment in agricultural cooperatives. Agribusiness, v. 25, n. 2, p. I8I-197, 2009.

PRATO, T., PAVEGLIO, T. An integrated conceptual framework for adapting forest management practices to alternative futures. International Journal of Forestry Research, p. I-13, 2014.

PUKKALA, T. Introduction to Multi-Objective Forest Planning. In: Multi-Objective Forest planning, Pukkala T (Ed). Managing Forest Ecosystems, Springer, p. I-19, 2002.

QUILLOY, K.P. Performance of the Sorosorolbaba Development Cooperative and Subasta Integrated Farmers Multipurpose Cooperative, Philippines. Journal of Economics, Management and Agricultural Development, v. I, n. I, p.72-84, 2015.
SHARIFI, O. Financial management and ratio analysis for agricultural cooperatives. Global Journal of Commerce and Management Perspective, v. 2, n. 4, p. I27-133, 2013.

TILAHUN, M., MAERTENS, M., DECKERS, J., MUYS, B., MATHIJS, E. Impact of membership in frankincense cooperative firms on rural income and poverty in Tigray, Northern Ethiopia. Forest Policy and Economics, v. 62, p. 95-108, 2016.

TOKSOY, D., YENIGÜN, M., SEN, G. Evaluation of agricultural development cooperatives in the forest villages by SWOT analyses (The case study in Maçka). Kastamonu Univ., Journal of Forestry Faculty, v. 9, n. I, p. 12-18, 2009.

YILMAZ, E., KELES, H., KOCAK, Z., Priority Determination of the Values of Forest Resources in Mersin Province. Eastern Mediterranean Forestry Research Institute Technical bulletin No:35, Turkey. 2010. 